\title{
発泡ポリスチロール融体の流動特性*
}

\author{
林 田建 世** 加藤 順 - ***
}

\section{Flow Characteristics of Foam Polystyrene Melt}

by

Kensei Hayashida and Jun'ichi Kato

(Faculty of Textile Science, Kyoto University of Industrial Arts and Textile Fibers, Kyoto)

The flow characteristics of foam polystyrene which contains $1.5 \mathrm{wt} \%$ butane were investigated and compared with those of polystyrene used for general purpose.

The apparent viscosity of foam polystyrene was lower than that of general polystyrene. This may be due to that the Brownian motion of polymer molecules becomes more active by the existence of minute bubbles and reduces the intermolecular force or friction (shearing stress). The non-Newtonian flow index of foam polystyrene was smaller than that of general polystyrene. This may be due to that the random Brownian motion of molecules becomes more active and thus makes harder the imperfect orientation of molecules arising from the increase in shear rate. The activation energy of flow of foam polystyrene was slightly smaller than that of general polystyrene, which may be due to that the molecules of foam polystyrene melt become more movable by the existence of minute bubbles.

Besides, the influences of pressure and temperature upon foaming pattern and foaming ratio were investigated, and it was found that the greatest foaming ratio can be obtained at the optimum temperature $\left(215^{\circ} \mathrm{C}\right)$ for extruding general polystyrene, and, at constant temperature, a good skin of extrudate can be obtained only when the extruding pressure exceeds a certain limit value.

(Received Oct. 28, 1972)

\section{1 緒言}

最近高分子と他の物質との複合材料が注目されてき たが，発泡ポリマーもポリマーとガスとの複合体と考 えら机る。さて, 発泡ポリマーの溶融体の流動特性を 知ることは，成形機特よびダイの設計，あるいは成形 の管理等に拈いてきわめて重要であるばかりでなく， このような複合体の流動性を調べることにより非ニュ 一トン性流動機構等に関する知見る得ることができる と考党られるが，これに関する報告はまだきわめて少 ない. 本研究に抒いては発泡ポリスチロール拈よび一 般用ポリスチロールの溶融物の見掛け流動特性の比較 を行ない, ガスの存在が流動特性, 見掛け粘度等に及 ぼす影響を検討し，若干の考察を試みた。また発泡状 態掞よび発泡倍率に及ぼす温度，圧力の影響について も検討を行なった。

\section{2 実}

\section{験}

\footnotetext{
* 原稿受理 炤和47年10月28日

** 正会員 京都工去䌩維大学纎維学部

京都市左京区松ヶ崎御所海道町

*** 京都工芸䄉維大学瀻維学部 京都市左京区松ヶ㱦御所海道町
}

\section{$2 \cdot 1$ 計算式}

融体の非ニュートン流動特性は次式で表わされる。

$$
\eta_{*}{ }^{\prime} D_{w}{ }^{\prime}=\tau_{w}{ }^{\prime}{ }^{\prime}
$$

ここに， $n^{\prime}$ は見掛讨非ニュートン性指数， $\eta_{*}^{\prime}$ は見 掛忛粘性係数，また $D_{w}{ }^{\prime}$ 呿よび $\tau_{w}{ }^{\prime}$ は管壁面に抢け る見掛けせ九断速度㧍よび見掛けせ九断応力で，それ ぞれ次式で計算される。

$$
\begin{aligned}
D_{w}{ }^{\prime} & =\frac{4 Q}{\pi R^{3}} \\
\tau_{w}{ }^{\prime} & =\frac{P R}{2 L}
\end{aligned}
$$

ここに，Lは円管長， $R$ は管半径，木た $P$ おび $Q$ はそれぞれ押出し圧力拉よび押出し容積流量である。 また見脚け粘度 $\eta_{a}$ は次式で計算される。

\section{$2 \cdot 2$ 試料}

$$
\eta_{a}=\frac{\tau_{w}{ }^{\prime}}{D_{w}{ }^{\prime}}
$$

使用した試料は平均分子量が53.3万, 密度が 1.0525

$\left(30^{\circ} \mathrm{C}\right)$ である一般用ポリスチレン（以下 PSGP で 示す）拈よび平均分子量が53.3万, 気体（ブタン）含 有率が $1.5 \mathrm{wt} \%$ である発泡ポリスチロールのビーズ 
（以下 FPS で示す）である。な特気体含有率は減量

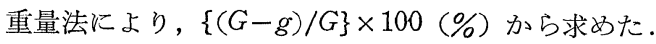
ここで, $G$ は発泡ビーズの重量, $g$ は発泡ビーズから 気体の一部が逸脱した後の重量である。

\section{$2 \cdot 3$ 実験装置}

実験装置は Fig. 1 亿示すよらなスクリュウ押出し機 を使用した. Table I はとの仕様を示す．スクリュウ はメタリング型のものを使用した。またホッパー付近 での樹脂の融着とビーズの発泡を防止するためにスク リュウ冷却とバレル冷却を行なった。回転数はリング コーン無段変速機で変化させた，使用したダイは長さ $L=14 \mathrm{~mm}$, 直径 $2 R=2.8 \mathrm{~mm}(L / R=10)$ の円孔， ズルを有するもので，ノズルの流入部分は半円すい角 $45^{\circ}$ のテーパーをつけてあり，流入端効果，すなわち 管長補正係数ができるだけ小さくなるようにした。

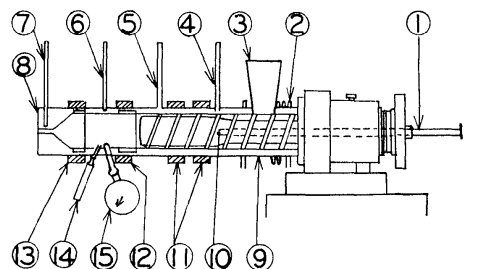

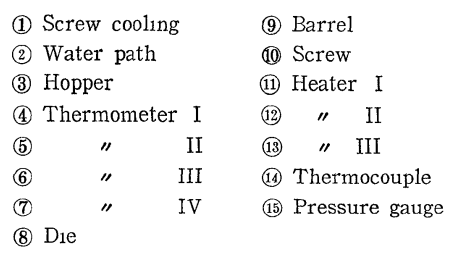

Fig. 1. Experimental Apparatus.

Table I. Specifications of experimental extruder.

\begin{tabular}{l|c}
\hline Screw diameter, $D(\mathrm{~mm})$ & 25 \\
Effective length of screw, $L(\mathrm{~mm})$ & 350 \\
$L / D(-)$ & 14 \\
Compression ratio, (-) & 2 \\
Motor output, (P) & 1 \\
Range of revolutions, (r.p.m.) & $4 \sim 45$ \\
\hline
\end{tabular}

\section{$2 \cdot 4$ 実験方法}

押出し運転状態でヒータIを調節し, Table II に 示すように温度分布を設定し，各スクリュウ回転数に 対して樹脂温度（熱電対により直読）が所定の值にな るよらにヒータ II , IIIを調節し, 各押出し圧力 $P$ (ブ ルドン管式圧力計により測定）と押出し質量流量との 関係を実測した。また比容積対温度の関係をデイラト メータによって測定し，押出し質量流量を押出し容積 流量Q海算した。な䄮発泡ポリスチロールのビーズ の溶融体の場合には，ガス含有量が少なく，ぬたわれ
Table II. Resin and barrel temperature.

\begin{tabular}{|c|c|c|c|c|}
\hline Symbol for FPS temperature & A & B & $\mathrm{C}$ & $\mathrm{D}$ \\
\hline Symbol for PSGP temperature & $A^{\prime}$ & $B^{\prime}$ & $\mathrm{C}^{\prime}$ & $D^{\prime}$ \\
\hline $\begin{array}{l}\left.\text { Resin temperature ( }{ }^{\circ} \mathrm{C}\right) \\
\text { (Thermocouple) }\end{array}$ & 192 & 205 & 215 & 228 \\
\hline $\begin{array}{l}\text { Barrel temperature }\left({ }^{\circ} \mathrm{C}\right) \\
\text { (Thermometer I) }\end{array}$ & 115 & 115 & 115 & 115 \\
\hline $\begin{array}{l}\text { Barrel temperature }\left({ }^{\circ} \mathrm{C}\right) \\
\text { (Thermometer II) }\end{array}$ & 170 & 170 & 170 & 170 \\
\hline $\begin{array}{c}\text { Adapter temperature }\left({ }^{\circ} \mathrm{C}\right) \\
\text { (Thermometer III) }\end{array}$ & 180 & 190 & 200 & 210 \\
\hline $\begin{array}{c}\text { Die temperature }\left({ }^{\circ} \mathrm{C}\right) \\
\text { (Thermometer IV) }\end{array}$ & 150 & 160 & 160 & 170 \\
\hline
\end{tabular}

われの実験に括ける観察によると，発泡はノズルを出 た直後に起こって括り，ノズル中の流動に扮いてはま だガスが外周条件（容器拉よび融体の粘弾性）のため に膨張を抑圧された状態に岉るとみられることから， ノズル流動中のガスの容積は無視できるものとして, 一般用ポリスチロール融体の比容積で代用した。また ダイ温度はアダプター温度より約 $30^{\circ} \mathrm{C}$ 低めに保ったが， これは押出し物表皮部分の温度を下げて発泡を容易に するためである。

\section{3 結果および考察}

\section{$3 \cdot 1$ 流動特性}

Fig. 2 は見掛けせ几断速度 $D_{w}{ }^{\prime}$ と見掛政せ九断応力 $\tau_{w}{ }^{\prime}$ 之の関保，すなわち見掛けの流動特性を示す．2. 3 で述べたように本実験では流入端損失，または管長 補正係数は小さいと考光られるので，これらの見掛け の流動特性は真の流動特性にかなり近いもの之考党ら

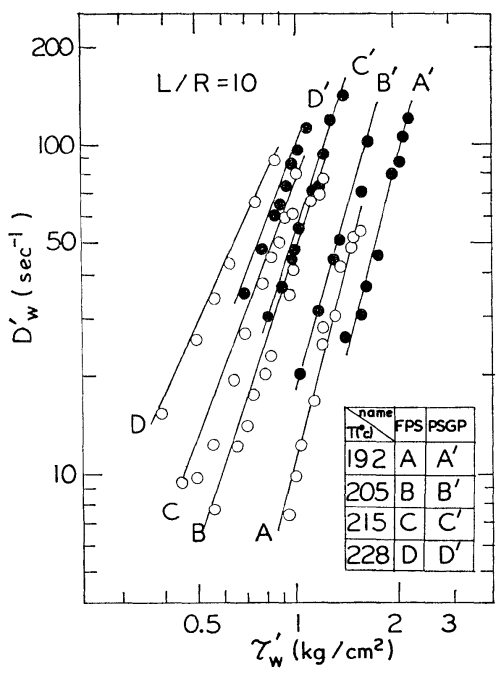

Fig. 2 Apparent flow characteristics of general (general purpose) polystyrene melt (GPPS) and foam polystyrene melt (FPS); $D_{w}{ }^{\prime}$ : apparent shear rate, $\tau_{w}^{\prime}$ : apparent shear stress. 
れる。図中黒丸は一般用ポリスチロール融体，白丸は 発泡ポリスチロール融体を示す（以下同様とする）. 同一温度についてみれば白丸の方が黒丸より左側にあ ることから, 発泡ポリスチロール融体の方が流れやす いことがわかる．これらの見掛けの流動特性は実験範 囲内で浪注直線で表わされるから，そのこら配から見 掛忊非ニュートン性指数 $n^{\prime}$ が求められる。【たがっ てまた見掛け粘性係数 $\eta_{*}{ }^{\prime}$ も求められる。

\section{$3 \cdot 2$ 見掛け粘度}

Fig. 3 は見掛将粘度 $\eta_{a}$ と見掛けせ九断速度 $D_{w}{ }^{\prime}$ と の関係を示す．各温度とも，見掛粘度は一定せん断 速度では発泡ポリスチロール融体の方が一般用ポリス チロール融体より低いことがわかる．さてブタンの熱 力学的状態図から本実験で用いたノズル内温度物よび 圧力に持いてはブタンはガス状態とみなされ，発泡ポ リスチロール融体ではブタンガスが高分子鎖間に微細 な気泡として分散していると考えられる。この微細な 気泡の存在のために高分子鎖のブラウン運動が比較的 活発となり，これが分子間力，すなわら摩擦力を緩め るので, 同一温度, 同一せん断速度で, 発泡ポリスチ ロール融体の見掛け粘度の方が低くなるのであろうと 考觉らる。

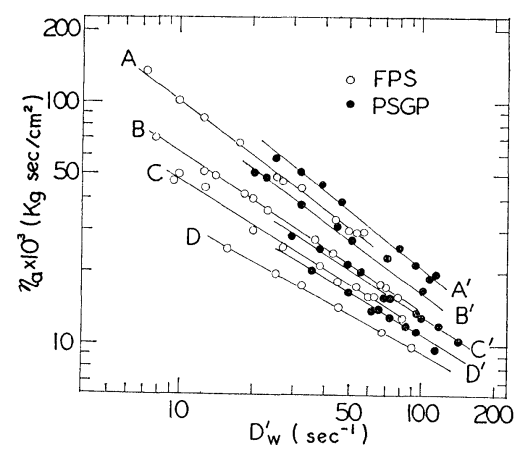

Fig. 3. Relation between apparent viscosity $\eta_{a}$ and apparent shear rate $D_{w}{ }^{\prime}$ at several temperatures.

つぎに Fig. 3 に抹いてせん断速度が増加する際に， 見掛水粘度は両試料とも直線的に減少している。これ はせん断速度の増加とともに，せ九断方向に高分子鎖 の未完成配向の增加を生じ，そのために速度こう配に よる運動量の伝達が減少するので, 見掛け粘度が減少 するといら効果を生ずるものと考光られる。

しかし発泡ポリスチロール融体の方がその効果がや や小さいことが認められるが，その原因として微細な 気泡の存在のために，高分子鎖のランダムなブラウン 運動が比較的活発となるために, せ九断速度（速度こ ら配）の増加による高分子鎖の未完成配向の増加が削 減されて上記効果がより少なくあらわれるのであろう
と思われる。

いま(1)式を(4)式に代入すれば，非ニュートン性領域 で次式が成立する。

$$
\eta_{a}=\eta_{*}{ }^{1 / n^{\prime}} \cdot D_{w}{ }^{1 / n^{\prime}-1}
$$

この両辺の対数をとれば

$$
\log \eta_{a}=\frac{1}{n^{\prime}} \log \eta_{*}{ }^{\prime}+\left(\frac{1}{n^{\prime}}-1\right) \log D_{w}{ }^{\prime}
$$

となり，一定温度で $n^{\prime}$ は一定值であるから， Fig. 3 の各直線のこう配は $\left(1 / n^{\prime}-1\right)$ となることがわかる. Fig. 3 で同一温度では発泡ポリスチロール融体の方が 直線の傾きがやや緩やかである.すなわち $\left|1 / n^{\prime}-1\right|$ がやや小さく, これは非ニュートン性指数 $n^{\prime}$ は発泡 ポリスチロール融体の方がやや小さくなることを意味 する.

\section{$3 \cdot 3$ 見掛け非ニュートン性指数および見掛け粘性 係数}

Fig. 4 は見掛け非ニュートン性指数 $n^{\prime}$ 打よび見掛 け粘性係数 $\eta_{*}{ }^{\prime}$ と温度 $T$ との関係を示す.同一温度で $n^{\prime}$ は発泡ポリスチロール融体の方が一般用ポリスチロ ール融体より低い值を示す．これは $3 \cdot 2$ の後半で述 ベた理由によると考学られる．また温度が高くなるに つれて両者の隔たりも大きくなるのがみられる。これ は温度が高くなるにつれて高分子鎖のブラウン運動が より活発となるので, 両者とも非ニュートン性は減少 するが，微細な気泡が存在する場合にはブラウン運動 も一層活発になるのでその傾向が一層著しくなるもの と思われる。また見掛忷粘性係数 $\eta_{*}{ }^{\prime}$ は粘度の次元を もたないので真の物理的意味の粘度ではないが, 工学 的応用計算に括いて $n^{\prime}$ と並んで重要性をもっている.

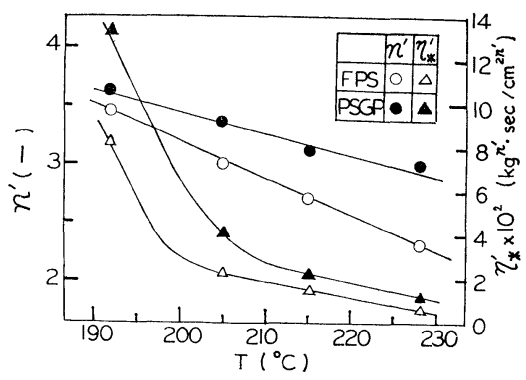

Fig. 4. Dependence of apparent non-Newtonian flow index $n^{\prime}$ and apparent coefficient of viscosity $\eta_{*}^{\prime}$ upon temperature.

\section{$3 \cdot 4$ 活性化エネルギ}

Fig. 5 は見掛けせ九断速度 $D_{w}{ }^{\prime}=60 \mathrm{sec}^{-1}$ のときの 見掛沙粘度 $\eta_{a}$ と絶対温度の逆数 $1 / T$ との関係を示す. その他の見掛けせん断速度の場合も同様に直線となっ た.これらの直線のこら配から流動の見掛け活性化エ ネルギ $E_{a}$ を求めた．Fig. 6 は見掛け活性化ェネルギ $E_{a}$ と見掛けせ九断速度 $D_{w}{ }^{\prime}$ との関係を示す，同一せ 


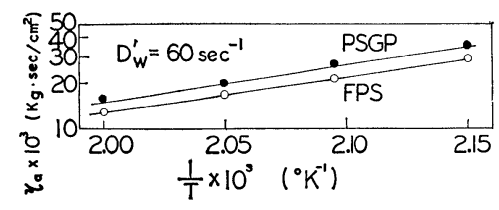

Fig. 5. Relation between apparent viscosity $\eta_{a}$ and $1 / T$ ( $T$ : absolute temperature).

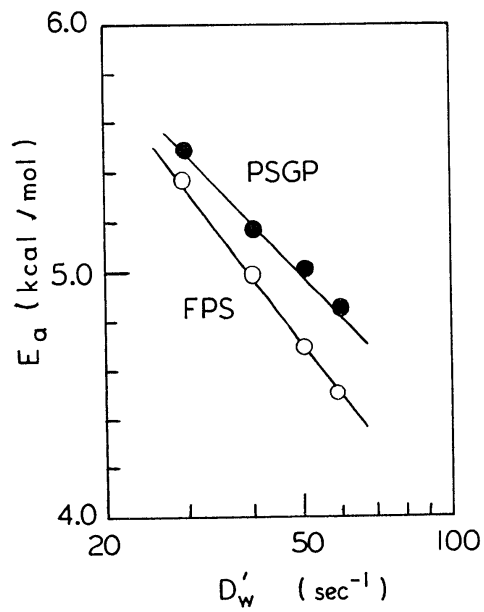

Fig. 6. Apparent activation energy of flow $E_{a}$ vs, apparent shear rate $D_{w^{\prime}}$.

ん断速度に扣いて， $E_{a}$ は発泡ポリスチロール融体の 方が一般用ポリスチロール融体より少し小さいことが 認められる。これは発泡ポリスチロール融体では微細 な気泡の存在のために高分子鎖がやや動きやすくなっ ているためであるらと思われる。

\section{$3 \cdot 5$ 発泡状態および発泡倍率}

発泡は融体がダイを出た直後に起こり, 小さい気泡 が次々とより大きい気泡内に拡散し, 融体粘度が適度 であれば気泡が融体に囲まれた状態で適度な大ささに 発泡し，まもなく表面から冷却固化して表面に比較的 硬いスキンを持つ発泡体となる. Fig. 7 は温度 $205^{\circ} \mathrm{C}$ および $215^{\circ} \mathrm{C}$ の場合の発泡状態を示す. この場合, 低 圧域（約 $15 \mathrm{Kg} / \mathrm{cm}^{2}$ 以下）では同左図のよらにダイ 出口に接近して発泡が開始され, 押出し物表面はさめ はだに近いスキンとなった。これに対して，上記以上 の高圧域ではダイから 15 20 mm 位離れて発泡が開 始され，良好なスキンを持つ発泡体が得られた。

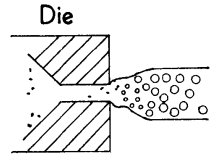

At low pressure

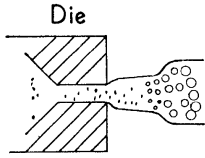

At high pressure
Fig. 7. Foaming patterns.
Fig. 8 は各温度に和ける発泡倍率 $\beta$ と押出し圧力 $P$ との関係を示す. 発泡倍率 $\beta$ としては，常温に打ける 発泡押出し物の比容積を一般用ポリスチロール(固体) の比容積で割った値を用いた。 Fig. 8 から，一般に温 度，圧力が高いほど $\beta$ は大きいこと，樹脂温度が高く なるにつれて低い圧力で高い発泡倍率が得られること， 同一温度では圧力の増加につれて発泡倍率はあるとこ ろまでほぼ直線的に増加するが，それ以後の発泡倍率 の上昇割合は減少すること, 温度が高いほど発泡倍率 上昇の直線部分のこう配が大きくなることがわかる。

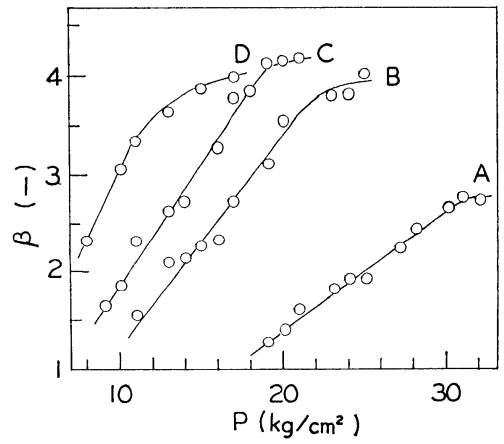

Fig. 8. Relation between foaming ratio $\beta$ and pressure $P$ at several temperatures.

つぎに, 温度が比較的低い場合(A)には, 発泡に要す る圧力は高くなるが発泡倍率は小さい。これは融体の 粘度が高く，また弾性も大きいために発泡が押えられ るためと考光られる．温度が比較的高い場合(D)には， 融体の粘度は低く弾性も小さくなるので, 押出し圧力 は低くなるが, 発泡倍率は大きくなり, 発泡はダイ出 口に接近して開始され，大さな気泡を持つ表面に山凸 の多い悪い発泡体が得られる。温度が適当な場合（B， C), 特に最適温度 (C)の場合に, 本実験に打ける最大 発泡倍率が得られた。これは一般用ポリスチロールの 最適押出し温度とだいたい一致する。

終わりに資料を提供していただき，また有益な御助 言をいただいた積水化成品（株）の諏訪勝彦部長に深 謝する.

（昭和 47 年 7 月 8 日 第18回高分子研究発表会にて講演）

\section{参 考 文 献}

1) Blyler, L. L., JR., and T. K. Kwei, J. Polymer Sci., Part C, No. 35, 165 (1971).

2) Bernhardt, E. C., "Processing of Thermoplastic Materials”, Sect. 1 (1960) Reinhold Publishing Corporation, New York 